\title{
Effectiveness of m-Learning Applications for Design and Technology Subject
}

https://doi.org/10.3991/ijim.v13i10.11324

\author{
A. Shah, Suhailiezana ${ }^{(凶)}$, Che Ghani Che Kob \\ Universiti Pendidikan Sultan Idris, Perak, Malaysia \\ suhailiezana@gmail.com \\ M. Khairudin \\ Universitas Negeri Yogyakarta, Indonesia
}

\begin{abstract}
This study aims to evaluate the effectiveness of teaching aids using M-Learning application for Design and Technology Subjects. A total of 30 students Design and Technology subjects Form 1 of Kubang Kerian High School, Kelantan have answered the questionnaire. This questionnaire consists of five constructs namely Information design, Interaction design, showcase design and Training design (Sketch). This app was developed using ADDIE model. The overall findings of the research showed that the students were difficult to understand the topic of Pictorial Sketch was 2.45 at moderate level. After the study was conducted with the application of EZ Pictorial, the overall study findings rose at a high level of 4.64. This app enhances the level of understanding of the students and provides students with a fun learning situation. It is believed that this app will encourage student to learn difficult subject thus increase the performance of student achievement.
\end{abstract}

Keywords-M-Learning; smartphones; ICT

\section{Introduction}

Fingertip technology is a very synonymous thing used today to help people learn various things. The use of technology such as computers, tablets and smartphones to transmit information and receive information can be used anytime and anywhere [1]. Information technology had a huge impact in the education world where the atmosphere and style of learning have also changed. The use of ICT technology is one of the many teaching aids or tools used in the teaching process. However, the use of teaching aids is still inadequate, especially teaching aids involving the latest ICTs [2]. Teachers still use the method or technique of reading textbooks solely in their teaching and cause students to be less interested in being active in the classroom [3]. In addition, teachers are not creative in selecting, editing and rebuilding teaching materials from existing materials. The use of teaching aids is a way to improve achievement and success for students because without teaching aids, the learning 
process will be less quality and effective as well as academic achievement will decrease [4].

The use of technology is in line with the digital learning style in which students are more creative and innovative, and able to produce high quality work with the help of technology media in the teaching and learning process. Smartphones are the most widely used technology requirements today. In the content of smartphones there is a platform called the app. App is an abbreviation for application software which can be downloaded on application storage like app store and google play store. Many educational apps can be downloaded for free by users [5]. So the researcher wants to make the app a learning platform and reference material for teaching aids as students can freely load learning materials and can be used at any time even outside school hours.

Design and technology replace the integrated life skills subjects that have been implemented since 1988 [6]. Among the design criteria taught to students is design using technology in product development so individuals with global thinking are able to understand technology and ultimately solve future problems. However, students are still weak in some subjects such as isometric painting [7]. Isometric paintings, oblique paintings and some types of paintings are one of the subtopics found in the Pictorial topic for Form Design and Technology subjects. Students visualization skills are still at a weak level. This is because the main factor that causes poor visualization skills is that teachers are difficult to convey information to the students by using only printed modules [8]. In general, sketchy learning requires high levels of imagination, creative thinking, and observation and questioning skills. Students are required to understand and master many basic concepts, mastery of the diagram in the topic of the pictograms. Failure to master the Basic concept will result in failure to understand, interpret, and solve other problems. Without a clear understanding of the concepts or basic skills taught at the earliest stage of learning, the next learning process will be hindered and difficult.

Due to some problems such as weaknesses in traditional teaching and learning, the problem of governance weakness E Learning and lack of E-Learning use guidelines is one of the problems faced in education. Therefore, the researcher found that the use of M-Learning in learning can overcome the problems faced before. Learning in MLearning has proven its effectiveness in the outside world [9]. The sharing of notes among students has been facilitated by the availability of mobile devices such as smartphones among students. However, M-learning has never been optimized by students as it's not all compatible with smartphones used by students. The content of M-learning is still not compatible with the needs of students. [10].Thus the objective of this study is to evaluate the effectiveness of Teaching EZ Application for Teaching Aids in M-Learning Methods for Design and Technology Subject Form 1. 


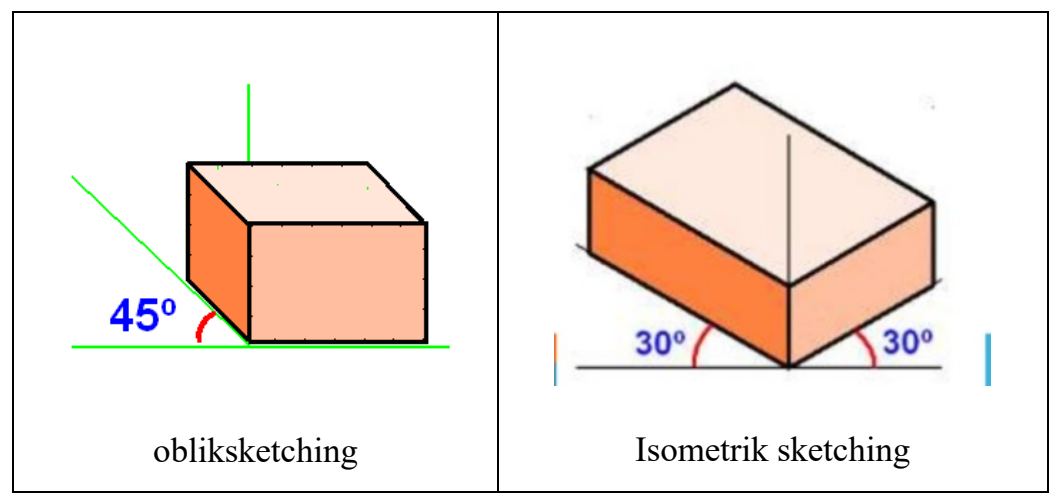

\section{Development of the EZ Pictorial Application}

This EZ Pictorial application was developed based on ADDIE Model adaptation. Based on the ADDIE model, the development of this module contains five (5) phases, namely the phase of need analysis, the design phase, the development phase, the implementation phase and the final evaluation phase [11]. This model was introduced by Rosset in 1987. Additionally, the ADDIE model is a generic model that is very useful in designing a product because of its easy-to-understand nature. Additionally, the ADDIE model is also one of the design models that is often the basis of other design models. [12]

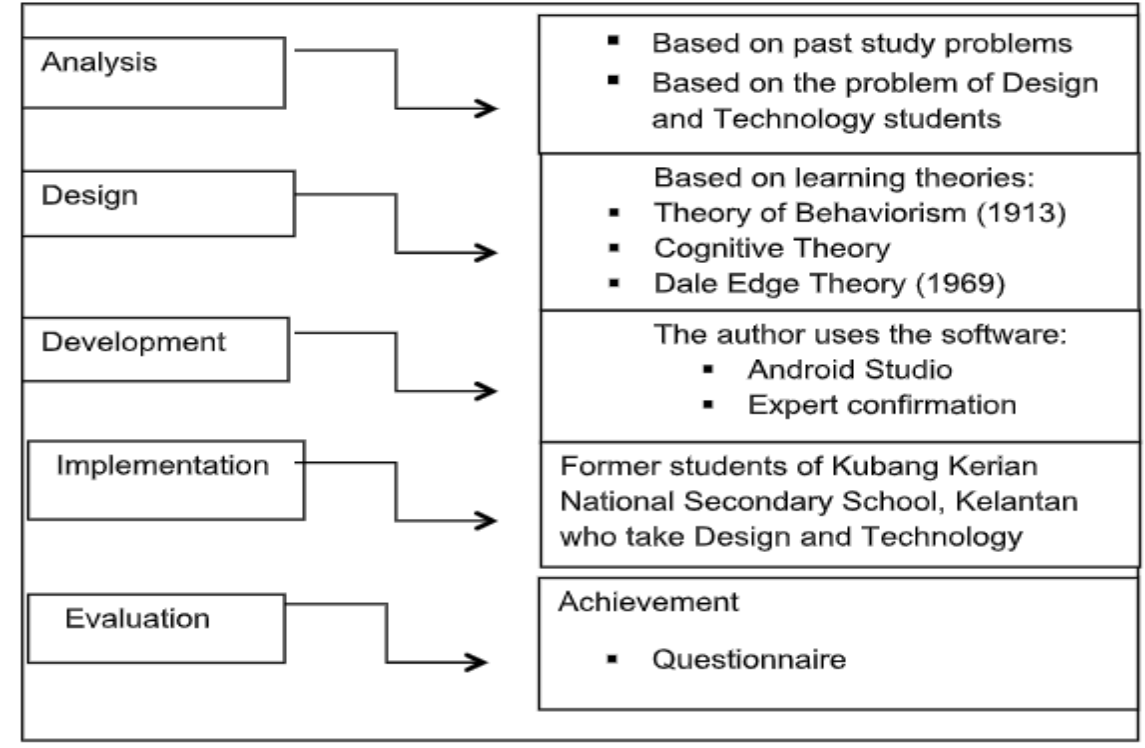

Fig.1. Summary of ADDIE model 


\subsection{Hand drawing process}

The first process for generating the EZ Pictorial app is to make a sketch where the writer will draw on how the application pattern is. The researchers compile the notes, training and sketches that will be produced. A storyboard or known by a specific name, story board, is a storyline of the storyline for the product you want to produce. It also refers to the sketches or initial illustration by the researcher. The purpose of the storyboard is to facilitate the researcher to add ideas to the sketches to be produced. A storyboard or known by a specific name, story board, is a storyline of the storyline for the product you want to produce. It also refers to the sketches or initial illustration by the researcher. The purpose of the storyboard is to facilitate the researcher to add ideas to the sketches to be produced

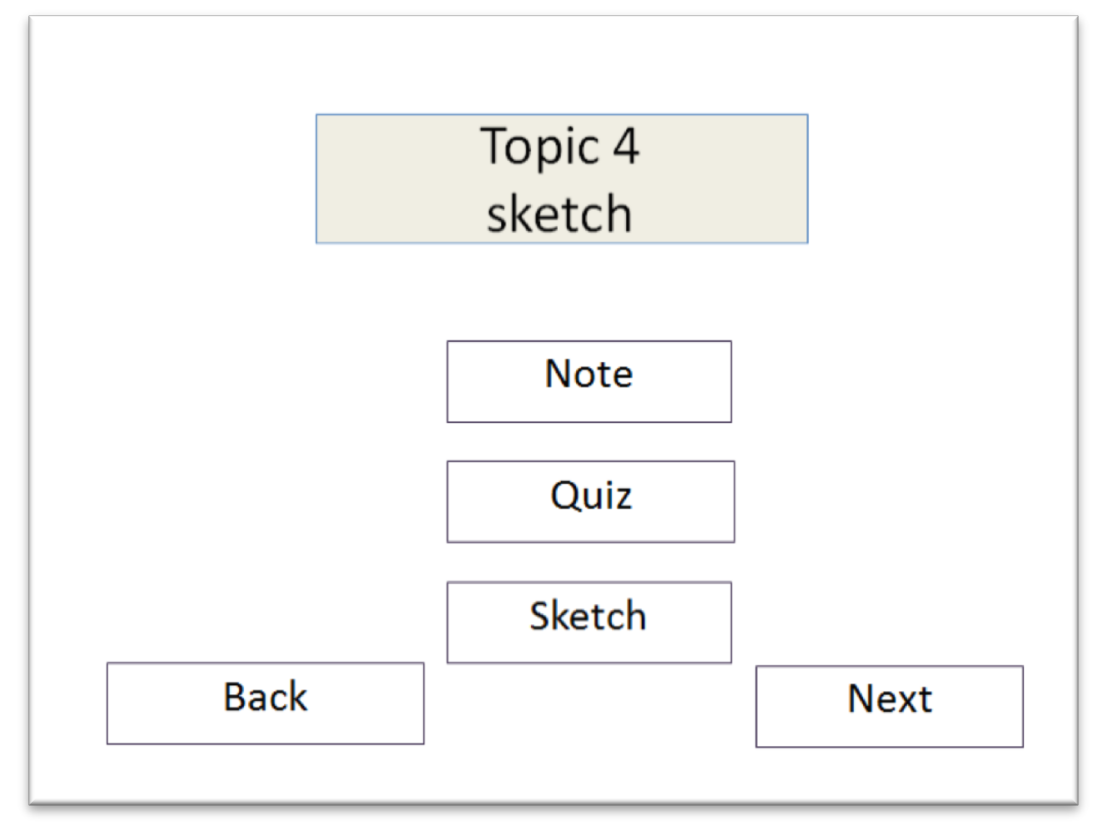

\subsection{Graphic drawing process}

From the handwriting will be transferred to a graphic sketch where researchers have used power point software to produce a preliminary description of the application 


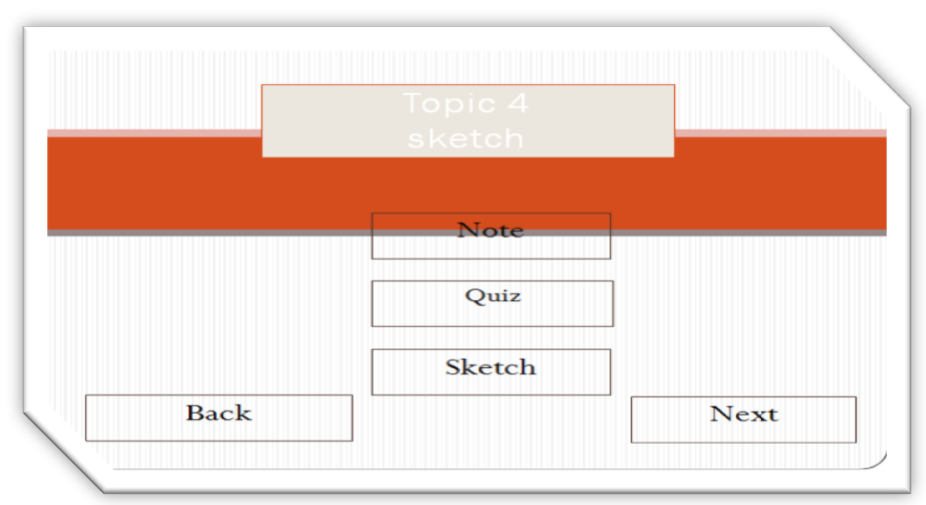

\subsection{Entering the coding process}

Then the note in the form of power point is moved into android studio software to make it an app. The process of inserting a coding is executed to place and create a button in the appropriate position so it can work.
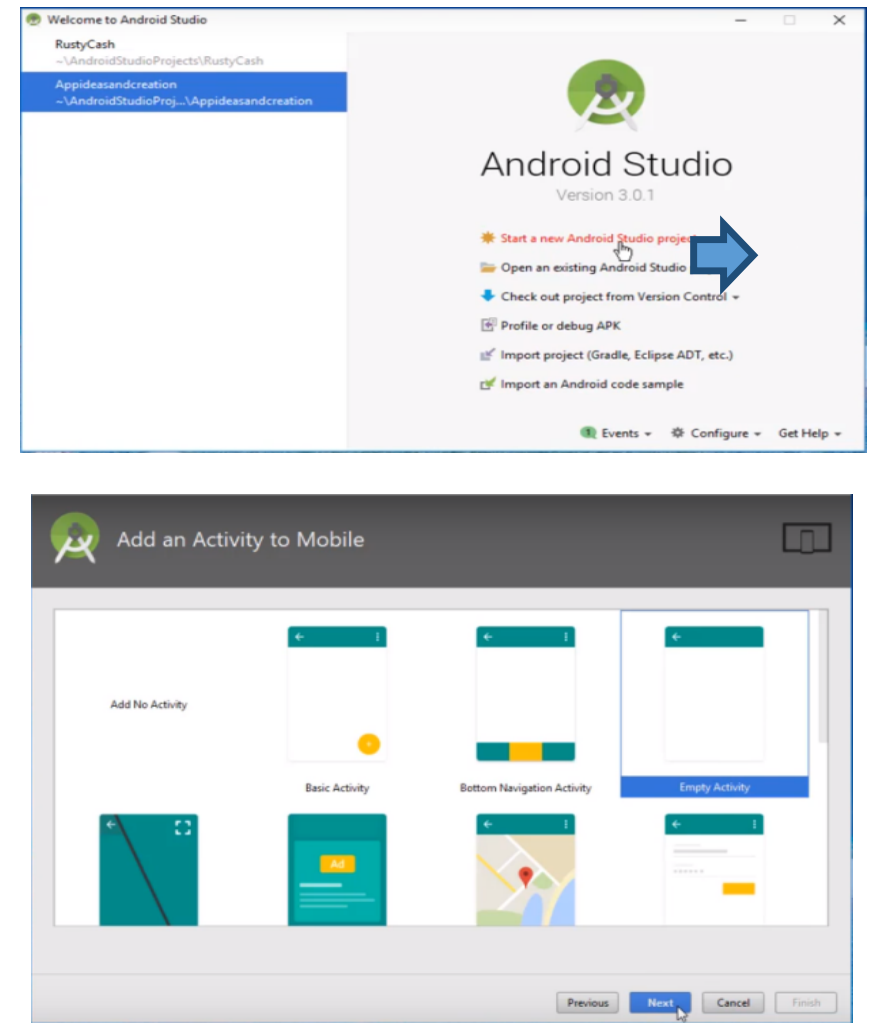
Paper-Effectiveness of m-Learning Applications for Design and Technology Subject
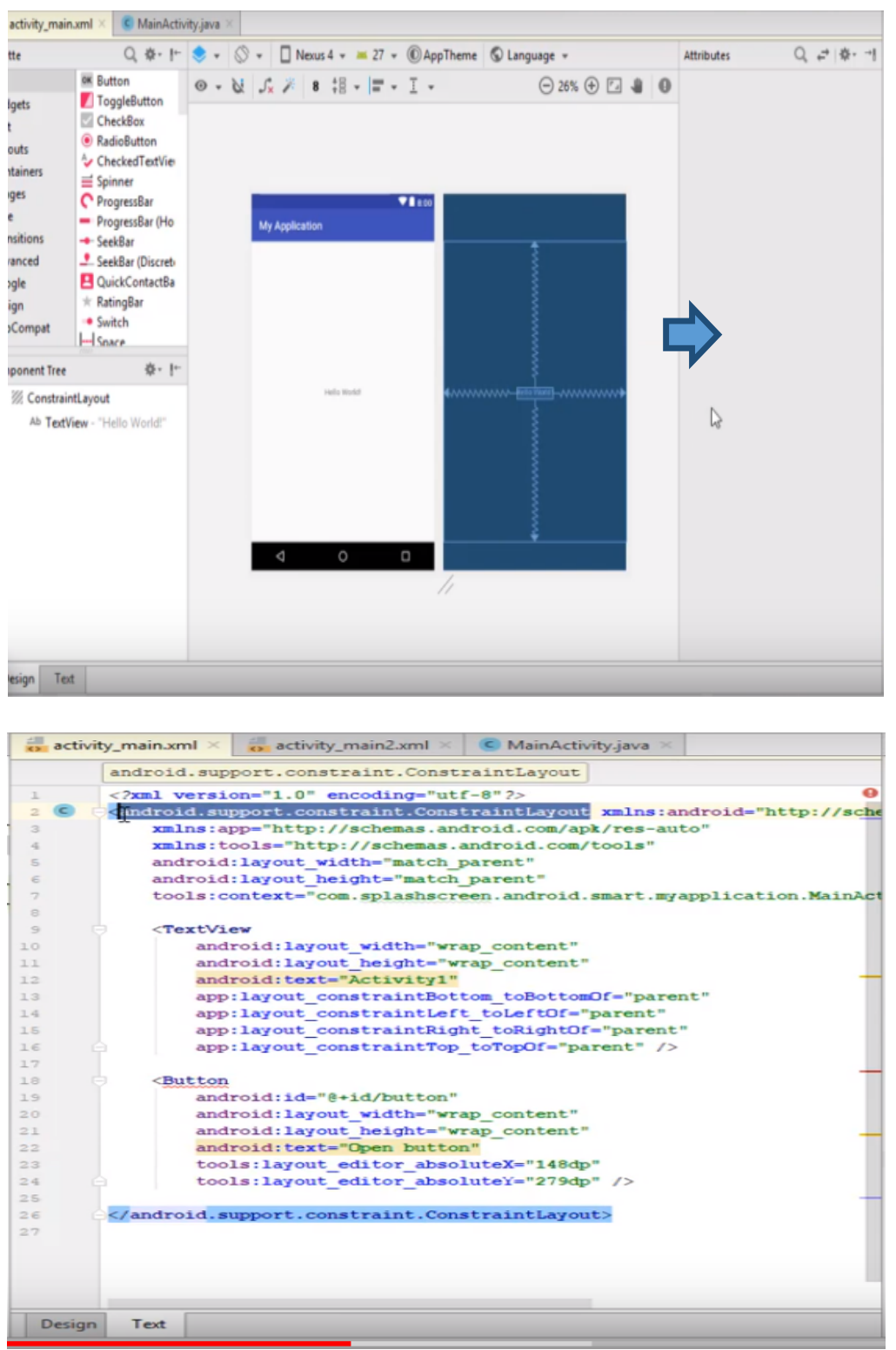


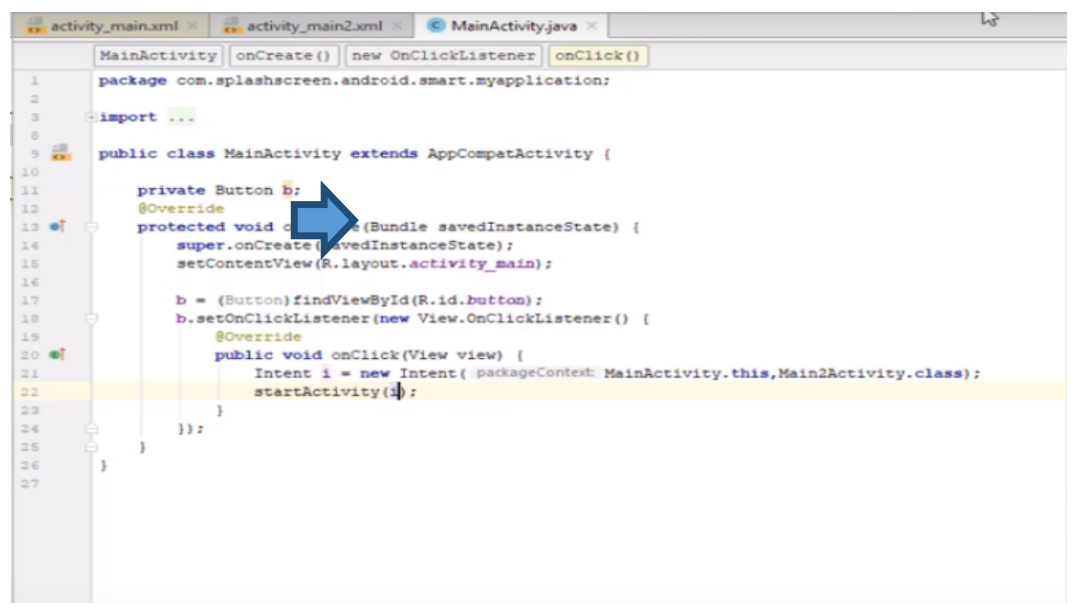

\subsection{Packaging process}

The packaging process is the last step where after completing the coding for button movement, the researcher reviewed the writing position, the suitability of the article, the use of color, the background and some other things.
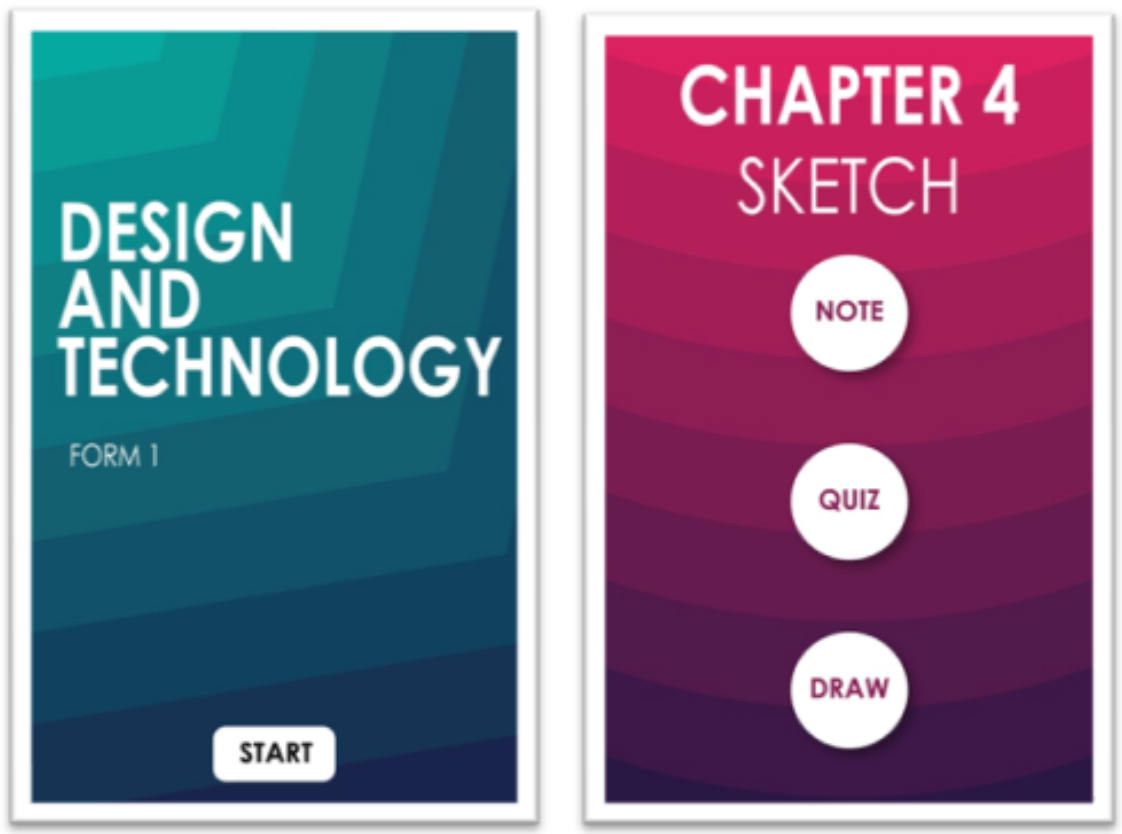


\section{$3 \quad$ Methodology}

The instrument of study is the most important measurement tool for achieving the objective of research [13]. Interesting instruments can encourage subjects to be tested to answer questions accurately and honestly [14]. The instrument is perfect, it can accurately measure a variable to measure. Questionnaire was used as the main instrument in this study which is commonly used in descriptive study. Questionnaires were conducted by constructing questions based on literature review and validated by expert teachers in the design subject and the questionnaire was completed by the respondents of the study and collected again to obtain information from the form. The information was then analyzed to answer the research questions. This questionnaire is divided into two parts: part A and part B. Part A refers to respondents 'demographics or backgrounds and part B refers to the needs of teaching aids and respondents' problems in the topic of pictorial sketches. This study was also conducted to evaluate the effectiveness of application of EZ pictorial application in Design and Technology Form 1 for the topic of Pictorial Sketch at Kubang Kerian National High School, Kelantan. The study involved 30 students from various genders. Questionnaire was also used to evaluate the effectiveness of application of EZ Pictorial application to facilitate respondents to answer questions. Respondents are required to mark $(\sqrt{ })$ one answer from the five (5) choices that are correctly considered for the questions submitted.

Table 1. Likert scale score

\begin{tabular}{|l|l|}
\hline 1 & Strongly disagree \\
\hline 2 & Don't agree \\
\hline 3 & Don't agree \\
\hline 4 & Agree \\
\hline 5 & Strongly agree \\
\hline
\end{tabular}

Data analysis is then made using the mean score. The mean score for measuring the response rate from the respondents was classified into three mean score scores with three levels namely low, medium and high as shown in Table 2. The data were recorded and processed using the computer through the SPSS program.

Table 2. Mean score

\begin{tabular}{|c|l|}
\hline Level & \multicolumn{1}{c|}{ The value of the fixed mark } \\
\hline 0.00 to 1.33 & Low \\
\hline 1.34 to 2.67 & Medium \\
\hline 2.68 to 4.00 & High \\
\hline
\end{tabular}

\section{$4 \quad$ The Finding}

The researcher discusses the results of the research that have been analyzed by using descriptive analysis method. The data and information of the findings were obtained through a set of questionnaires distributed to the respondents. To analyze 
this quantitative data, researchers use the IBM SPSS STATISTCS 23 software. The overall analysis of the findings related to the EZ Pictorial application is using descriptive analysis. Analysis of the findings is presented in the form of frequency tables and charts. Part A - Respondent demographic information

Table 3. Respondents distribution by gender

\begin{tabular}{|l|l|c|c|c|c|}
\hline & \multicolumn{5}{|c|}{ Gender } \\
\hline & & Frequency & Percentage & Valid percent & $\begin{array}{c}\text { Cumulative } \\
\text { percent }\end{array}$ \\
\hline \multirow{3}{*}{ Valid } & Male & 13 & 43.3 & 43.3 & 43.3 \\
\cline { 2 - 6 } & Female & 17 & 56.7 & 56.7 & 100 \\
\cline { 2 - 6 } & Total & 30 & 100 & 100 & \\
\hline
\end{tabular}

Based on the data generated by SPSS, studies conducted by researchers involved different sexes. Respondents were 30 students where $43 \%$ were male respondents and $57 \%$ were female respondents. Questionnaire - Part B.

Table 4.

\begin{tabular}{|l|c|c|c|}
\hline \multicolumn{1}{|c|}{ ABM requirement in RBT subject } & N & Mean & $\begin{array}{c}\text { Standard } \\
\text { deviation }\end{array}$ \\
\hline I enjoy learning the subject of RBT? & 30 & 5.00 & .000 \\
\hline I'm more excited if learning comes with ABM? & 30 & 5.00 & .000 \\
\hline I need learning using ABM in the subject of RBT? & 30 & 4.56 & .490 \\
\hline I do not understand if teachers only use textbooks and printed materials & 30 & 4.45 & .759 \\
\hline I need reference materials when studying at home & 30 & 4.55 & .510 \\
\hline
\end{tabular}

This section presents the findings of the study to see ABM's needs in the RBT subject. The overall mean on table 4 shows a high value of 4.00 out of 5 in which the majority of students need teaching aids in the subject of Design and Technology. This explains that students also do not understand if teachers only teach using textbooks only.

Table 5.

\begin{tabular}{|l|c|c|c|}
\hline \multicolumn{1}{|c|}{ Problems in the topic of photometry sketches? } & $\mathbf{n}$ & mean & $\begin{array}{c}\text { Standard } \\
\text { deviation }\end{array}$ \\
\hline I understand learning in the topic of pictorial drawings? & 30 & 2.30 & .470 \\
\hline I do not understand the learning in the topic of the pictograms? & 30 & 2.55 & .510 \\
\hline I can distinguish between oblique sketches with isometric sketches? & 30 & 3.40 & .503 \\
\hline $\begin{array}{l}\text { I am skilled in making isometric sketches, oblique sketches and } \\
\text { perspective sketches? }\end{array}$ & 30 & 2.05 & .686 \\
\hline I need ABM to sketch more easily? & 30 & 3.65 & .489 \\
\hline
\end{tabular}

The problem in the topic of the pictograms shows that the mean values are at a low and moderate level, indicating that the respondents have an understanding problem in the sketchy topic. the mean score of the students' understanding level is 2.55 which is at moderate mean while the mean value of ABM is 3.65. 


\subsection{Software effectiveness in terms of information design}

This section is intended to determine the effectiveness of product development in terms of information design that is suitable for use in the learning and facilitating process after being adopted by respondents. The information design is divided into 1 section which has 5 related questions to be answered by the respondent. The table below shows the findings from the questionnaires that have been conducted.

Table 6. Findings of effectiveness in terms of design of Information

\begin{tabular}{|l|c|c|c|}
\hline \multicolumn{1}{|c|}{ Question } & Information design & Mean & $\begin{array}{c}\text { Standard } \\
\text { deviation }\end{array}$ \\
\hline $\begin{array}{l}\text { The delivery methods contained in this software are in line with the } \\
\text { topics presented? }\end{array}$ & 30 & 4.4667 & .62881 \\
\hline The information presented is easy to understand? & 30 & 4.4000 & .67466 \\
\hline Delivery of software content is organized? & 30 & 4.3000 & .65126 \\
\hline Content delivery speed according to user capabilities? & 30 & 4.1333 & .77608 \\
\hline Content delivery can attract students? & 30 & 4.4000 & .62146 \\
\hline
\end{tabular}

Based on the table above, data shows the mean value and standard deviation obtained through the questionnaire. All questions are related to the way the content of learning is delivered in the topic of the pictograms. From the mean of the five questions, it can be seen that question 1 item "the delivery method in this software is in line with the topic presented" is the highest average mean of 4.4667. Meanwhile, item 5 questionnaire "content delivery attracted student interest" recorded the lowest mean of respondents is 4.4000

\subsection{Software effectiveness in terms of interaction design}

This section is prepared to find out the design of the developed product to be used as a teaching aids after adoption by respondents. This section contains a section of 5 questions that respondents need to answer. All these variables have been measured using a Likert scale between one (very disagree) to five (strongly agree). The table below shows the results of the study based on the interaction design obtained through the questionnaire.

Table 7. Findings of software effectiveness in terms of interaction design

\begin{tabular}{|c|c|c|c|}
\hline \multicolumn{4}{|l|}{ Interaction design } \\
\hline & $N$ & Mean & $\begin{array}{l}\text { Standard } \\
\text { deviation }\end{array}$ \\
\hline Can I control the presentation of information with this software? & 30 & 4.4667 & .68145 \\
\hline $\begin{array}{l}\text { Content presentation in the software is sequential according to the } \\
\text { content of learning? }\end{array}$ & 30 & 4.4667 & .57135 \\
\hline I'm good at using this software? & 30 & 4.0000 & .90972 \\
\hline I find it easy to reach the required information? & 30 & 4.3000 & .65126 \\
\hline Does this software encourage me to try it myself? & 30 & 4.1667 & .83391 \\
\hline
\end{tabular}


Based on the above table, the data shows the mean value and standard deviation obtained through the questionnaires that have been conducted. Through these tables there are 5 questions items related to the interaction skills or user skills to use the app. From the mean of the 5 questions, it can be seen that item 1 question "I can control the presentation of information with this software" gets the highest average mean value of 4.4667 and standard deviation with the value of 0.68145 . This indicates that students are able to control the information obtained through this application. Meanwhile, the lowest average mean value is for question 3 item "I'm good at using this software" with average mean value of 4.0000 and standard deviation of 0.90972 .

\subsection{Software effectiveness in terms of presentation design}

This section is developed to determine the effectiveness of the application in terms of presentation design that can be used as a teaching tool in school. There are 5 question items were built to test the effectiveness of the application in terms of presentation design. The table below shows the findings from the questionnaire.

Table 8. Finding the effectiveness of the software in terms of presentation design

\begin{tabular}{|c|c|c|c|}
\hline \multicolumn{4}{|l|}{ The design of the show } \\
\hline & $N$ & Mean & $\begin{array}{c}\text { Standa } \\
\text { rd } \\
\text { deviati } \\
\text { on } \\
\end{array}$ \\
\hline Attractive screen design? & 30 & 4.2333 & .72793 \\
\hline The use of clear and easy-to-read text? & 30 & 4.3667 & .76489 \\
\hline The graph used is interesting? & 30 & 4.2000 & .84690 \\
\hline The color used is appropriate? & 30 & 4.3667 & .80872 \\
\hline $\begin{array}{l}\text { Background sound does not interfere with my focus on learning } \\
\text { content? }\end{array}$ & 30 & 4.0333 & .99943 \\
\hline
\end{tabular}

Based on the table above, data shows the percentage of mean and standard deviation obtained through the questionnaire. Through the table above, the highest average mean is for Item 3 item "Color used is appropriate" with average mean value 4.3667 and standard deviation 0.80872. While the lowest average mean value is in question 5, "Background sound does not interfere with the focus of learning content". The mean value of the question is 4.0333 and the standard deviation 0.99943. This suggests that the background sounds contained in the app are slightly disruptive for students in understanding the content of learning

\subsection{The effectiveness of the software in terms of training design (Sketch)}

The training section in the form of sketches was developed to evaluate the effectiveness of the use of training in sketches by students as respondents. There are 5 question items built to test app effectiveness in terms of training design (sketch). The table below shows the findings from the questionnaire. 
Table 9. Findings of effectiveness in terms of training design (sketch).

\begin{tabular}{|c|c|c|c|}
\hline \multicolumn{4}{|l|}{ Application usage in M-learning } \\
\hline Question & $N$ & Mean & $\begin{array}{l}\text { Standard } \\
\text { deviation }\end{array}$ \\
\hline know what M-learning method is? & 30 & 3.9333 & .73968 \\
\hline $\begin{array}{l}\text { Appropriate EZ Psychology application instructional materials are } \\
\text { used in M-learning method? }\end{array}$ & 30 & 4.2333 & .62606 \\
\hline $\begin{array}{l}\text { Can I study anywhere and anytime when using the M-learning } \\
\text { method? }\end{array}$ & 30 & 4.3667 & .55605 \\
\hline The M-learning method attracted me to study? & 30 & 4.3333 & .60648 \\
\hline
\end{tabular}

Based on the table above, the data shows the percentage of mean and standard deviation obtained through the questionnaire. Through the table above, the highest average mean is for question item 3 which is "I can study anywhere and anytime if using the M-learning method" with an average mean value of 4.3667 and standard deviation of 0.556053 . While the lowest average mean value is for question 1 , "I know what M-learning method" is. The mean value of the question is 3.9333 and the standard deviation of 0.73968 . Based on the findings of the questionnaire, many students have less exposure on M-learning.

The value of the mean score and the standard deviation of each product functionality

Table 10.

The mean score and the standard deviation as a whole

\begin{tabular}{|l|c|c|}
\hline \multicolumn{1}{|c|}{ Effectiveness } & Mean. Average & Standard Deviation \\
\hline Information design & 4.34 & 0.670454 \\
\hline Interaction design & 4.28002 & 0.729538 \\
\hline Showcase design & 4.24 & 0.829574 \\
\hline Training design (Sketch) & 4.36 & 0.901854 \\
\hline Knowledge in M-learning & 4.21665 & 0.632047 \\
\hline
\end{tabular}

Based on the data obtained in the table shows the overall mean score for each product functionality variable in the questionnaire. The table above shows the mean and standard deviation of the respondents' assessment through questionnaires that have been conducted. The effectiveness data for each of these functions is to know the advantages of the product to be used as ABM during the learning and facilitating process. There are five items tested for evaluating the effectiveness of the EZ Pictorial application product and the highest mean value is for the training design (Sketch) with mean mean value of 4.36000 and standard deviation is 0.901854 . The lowest mean mean value is for knowledge items in M-learning which is only 4.21665 with standard deviation of 0.632047 . The average mean value obtained to evaluate the effectiveness of application of EZ Pictorial application is at a high level. The average mean value obtained is at a high value and it indicates that the EZ Pictorial application is suitable for use as a teaching assistant in the PdPC process 


\section{Conclusion}

The effectiveness of the EZ Pictorial application has been successful when the three objectives of the study are well achieved. Researchers have successfully designing applications, producing applications and subsequently evaluating the effectiveness of application of EZ Pictorial application in M-learning for form students. The use of M-learning through mobile devices has given a tremendous impact on the teaching and learning process. The advancement of mobile wireless technology has enabled both faculty and students to study and obtain information flexibly regardless of time and location limits. With advanced technology and mobile devices. learning using mobile technology is not difficult to implement in our country and it can produce competitive students and master the generic skills of students as early as possible at school. With advanced technology and mobile devices, the implementation of M-learning is not a problem for implemented in our country and even the existence of M-learning in the educational process can produce innovative instructors and students with competitive standing with developed countries. this can be seen in previous studies showing that mobile device learning has been successfully implemented in developed countries..

\section{Acknowledgment}

The authors would like to express their highest gratitude to Universiti Pendidikan Sultan Idris (UPSI) for the funding of this research project (GPUBP) via code number 2018-0060-107-01.

\section{$7 \quad$ References}

[1] Kukulska-Hulme, A. (2012), "Mobile Learning and The Future Of Learning," International Review, 2, Pp.13-18.

[2] Mohd Yasin. M.H, Toran, H., Tahar, M.M., Bari, S.Ibrahim, S.N. D \& Zaharudin, R. (2013). Bilik Darjah Pendidikan Khas Pada Masa Kini Dan Kekangannya Terhadap Proses Pengajaran. Asia Pasific Journal of Educators and Education, Vol.28, 1-9.

[3] Che MohdNoor, C.M.S. Z \& Ahmad, A.R. (2015). Kreativiti Guru Dalam Meningkatkan Kefahaman Dan Penghayatan Sejarah. Fakulti Pendidikan. Universiti Kebangsaan Malaysia. https://doi.org/10.17576/geo-2019-1502-02

[4] Faizah Binti Ja'apar (2017). Bahan Bantu Mengajar (Bbm) Dalam Pengajaran Dan Pembelajaran (P\&P) Di Sekolah Menengah Kebangsaan (Smk) Daerah Pontian. Fakulti Pendidikan Teknikal Dan Vokasional Universiti Tun Hussein Onn Malaysia. https://doi.org/10.30880/jtet.2019.11.01.018

[5] C. Vinoth Kumar, Dr. J. Jayachandran. "Mobile Applications For Vocabulary Building Mobile Assisted Language Learning (Mall)"International Journal of English Language, Literature in Humanities Vol. 7 ( 2019 )

[6] Bahagian Pembangunan Kurikulum, "Kurikulum Standard Sekolah Menengah Reka Bentuk dan Teknologi Tingkatan 2," Putrajaya, 2016

[7] ArihasnidaAriffin, Norhasyimah Hamzah, Siti Nur KamariahRubani, Tamil Selvan 
[8] Subramaniam, Nurazmiera Mhd Razali (2017) Tahap Kemahiran VisualisasiBagi Mata Pelajaran LukisanKejuruteraan Di Uthm, ONLINE JOURNAL FOR TVET PRACTITIONERS, UTHM, 9, 1, ISSN: EISSN 2289-7410

[9] She, Y. \& Chen, J. (2011). Effect of problem-based, self-directed undergraduate education on life-long learning. Canadian Medical Education Journal. 148, 999-976.

[10] Norliza Binti A.Rahim (2013). Penggunaan Mobile Learning (M-Learning) Untuk Tujuan Pembelajaran Dalam Kalangan Pelajar Kejuruteraan Uthm Fakulti Pendidikan Teknikal Dan VokasionalUniversitiTun Hussein Onn Malaysia. https://doi.org/10. 21831/cp.v3i3.7340

[11] Sunismi (2015) Developing Guided Discovery Learning Materials Using Mathematics Mobile Learning Application as An Alternative Media for The Students Calculus II CakrawalaPendidik. XXXIV 3 334-346

[12] F. Hishamudin, "Model ADDIE,” Univ. Teknol. Malaysia, no. 1997, p. 1997, 2016.

[13] Nasohah, Ummu Nasibah, Muhammad Izuan Bin Abd Gani, Nazipah Binti Mat Shaid, and Md Shaid. "Model ADDIE dalam proses reka bentuk modul pengajaran: bahasa Arab tujuan khas di Universiti Sains Islam Malaysia sebagai contoh." In Proceeding of the International Semeanar on Language Teaching IseLT, pp. 4-5. 2015.

[14] S. Rajasekar et al., "Research Methodology," J. Math. Behav., vol. 68, no. s1, p. 23, 2006. https://doi.org/10.1093/intqhe/mzg031

[15] Kelley, Kate, Belinda Clark, Vivienne Brown, and John Sitzia. "Good practice in the conduct and reporting of survey research." International Journal for Quality in health care 15 , no. 3 (2003): 261-266

\section{Authors}

A. Shah is a Faculty member of Technical and Vocational, Universiti Pendidikan Sultan Idris

Suhailiezana Ellieza Binti Hassan holds a bachelor's degree in Living Skills Education at the University of Sultan Idris Education (UPSI), Malaysia. She is now pursuing a master's degree in Technical and Vocational Education (UPSI), Malaysia. Sheonce produced a tool for teaching Easy RBT applications for form 1 students and currently she developing another teaching aids for form 1 students namely the EZ Pictorial app.Suhailiezana@gmail.com

Che Ghani Che Kob is a Faculty of Technical and Vocational, Universiti Pendidikan Sultan Idris, 35900 Tanjong Malim, Perak, Malaysia.

M. Khairudin is a Mechatronics Engineering Education Department, Faculty of Engineering, Universitas Negeri Yogyakarta, Indonesia. His research areas include biomedical ultrasonics, image segmentation.

Article submitted 2019-07-03. Resubmitted 2019-07-28. Final acceptance 2019-07-28. Final version published as submitted by the authors. 